\title{
ASPIRASI ORANG TUA TENTANG PENDIDIKAN ANAK DI JORONG KAMPUANG PISANG NAGARI KOTO PANJANG KECAMATAN IV KOTO KABUPATEN AGAM.
}

\author{
Mutiara Putri Insani ${ }^{1}$ Yurni Suasti ${ }^{2}$ Ratna Wilis ${ }^{2}$ \\ Program Studi Pendidikan Geografi \\ Jurusan Geografi \\ Fakultas Ilmu Sosial \\ Universitas Negeri Padang \\ Email: mutiaputri1995@gmail.com
}

\begin{abstract}
ABSTRAK
Penelitian ini bertujuan untuk mendeskripsikan aspirasi orang tua tentang pendidikan anak di Jorong Kampuang Pisang Nagari Koto Panjang Kecamatan IV Koto Kabupaten Agam. Jenis penelitian ini adalah deskriptif kualitatif. Informan dalam penelitian ini adalah orang tua yang memiliki anak usia sekolah. Penelitian ini dikumpulkan dalam wawancara mendalam dan dianalisis melalui reduksi data, penyajian data, dan pengambilan kesimpulan. Penelitian ini menemukan: (1) Cita-cita orang tua terhadap pendidikan anaknya yaitu orang tua ingin anaknya menjadi dokter, guru, abdi negara, wanita karir, dan lain sebagainya. (2) Hasrat berkaitan dengan usaha orang tua untuk mewujudkan cita-cita orang tua terhadap anaknya, seperti memasukkan anak ke sekolah formal, orang tua tidak membedakan pendidikan antara anak laki-laki dan anak perempuan, bagi orang tua sama nilai keduanya, dan berusaha memenuhi kebutuhan anak walau sering terkendala biaya (3) Ketetapan hati berkaitan dengan kepuasan orang tua terhadap apa yang telah dicapai anaknya, orang tua merasa puas jika cita-cita mereka terhadap anak bisa terwujud.
\end{abstract}

Kata Kunci: Aspirasi, Cita-Cita, Capaian

\section{ABSTRACT}

This study aims to describe aspirations of parents about children's education in Jorong Kampuang Pisang Nagari Koto Panjang District IV Koto Kabupaten Agam. This type of research is descriptive qualitative. The informants in this study are parents who have school-age children. This research was collected in in-depth interviews and analyzed through data reduction, data presentation, and conclusions. This research found: (1) parents' aspirations for their children's education, namely parents want their children to be doctors, teachers, state servants, career women, and so on. (2) Desire is related to the efforts of parents to realize the ideals of parents towards their children, such as entering children into formal school, parents do not distinguish education between boys and girls, for parents both values, and trying to fulfill needs of children even though often constrained by costs (3) Determination of the relationship with parents' satisfaction with what their children have achieved, parents feel satisfied if their aspirations for children can be realized

Keyword: Aspiration, ideal, Accomplishement

\footnotetext{
${ }^{1}$ Mahasiswa Program Studi Pendidikan Geografi Fakultas Ilmu Sosial Universitas Negeri Padang ${ }^{2}$ Dosen Jurusan Geografi Fakultas Ilmu Sosial Universitas Negeri Padang
} 


\section{PENDAHULUAN}

Pendidikan adalah usaha sadar dan terencana untuk mewujudkan suasana belajar dan proses pembelajaran agar peserta didik secara aktif mengembangkan potensi dirinya untuk memiliki kekuatan spritual keagamaan, pengendalian diri, kepribadian, kecerdasan, akhlak mulia, serta keterapian yang diperlukan dirinya, masyarakat, bangsa, dan negara. (Undang-Undang No. 20 Tahun 2003)

Pendidikan adalah pondasi atau landasan yang kokoh bagi setiap masyarakat untuk dapat melakukan perubahan sikap dan perilaku. Pendidikan dapat membentuk manusia yang terdidik, cerdas dan terampil. Pendidikan juga mempunyai peranan penting dalam kehidupan perseorangan, masyarakat, bangsa dan negara. Maju mundurnya negara banyak ditentukan pendidikan di negara itu sendiri.

Pendidikan memberikan banyak harapan untuk masa depan seperti halnya harapan terhadap pemberantasan kebodohan, ketimpangan, dan juga menumbuhkan kesejahteraan akhirnya mampu menjadi daya tarik tersendiri ditubuh masyarakat. Mereka yang mampu melihat masa depan dari adanya pendidikan mempersiapkan sebaik mungkin untuk anak-anak mereka nantinya agar anak-anak mereka dapat keluar dari cengkeraman kebodohan dan juga kemiskinan.

Aspirasi berasal dari kata aspire, yang berarti bercita-cita atau menginginkan. Aspirasi merupakan harapan dan tujuan untuk keberhasilan pada masa yang akan datang (KBBI).
Menurut Hurlock (1999) aspirasia dalah keinginan akan sesuatu yang lebih tinggi dengan kemajuan sebagai tujuannya.

Menurut Slameto (2010) menjelaskan bahwa aspirasi merupakan harapan atau keinginan seseorang akan suatu keberhasilan atau prestasi tertentu. Ahmadi (2009) menjelaskan aspirasi sama dengan kemauan yaitu dorongan kehendak yang terarah pada tujuantujuan hidup tertentu, dan dikendalikan oleh pertimbangan akal budi.

Setiap orang tua mempunyai keinginan dan tujuan demi keberhasilan pendidikan anaknya pada masa yang akan datang. Orang tua ingin anaknya mendapatkan pendidikan yang baik dengan harapan setelah anak selesai menempuh pendidikan anak mendapatkan pekerjaan yang baik atau layak.

Data yang diperoleh dari Kantor Wali Nagari Koto Panjang, bahwa di Jorong Kampuang pisang bisa dilihat jumlah penduduk yaitu sebanyak 1503 orang, terdiri dari 739 orang penduduk laki-laki dan 764 orang penduduk perempuan. Jumlah KK sebanyak 437. Jumlah KK yang memiliki anak usia sekolah sebanyak 181. Jumlah anak yang sekolah pada masing-masing tingkatan, yaitu tingkat Taman KanakKanak berjumlah 12 orang, Sekolah Dasar/sederajat berjumlah 133 orang, SLTP/sederajat berjumlah 53 orang, SLTA/sederajat berjumlah 56 orang, dan Perguruan Tinggi berjumlah 19 orang. Sedangkan anak yang putus sekolah berjumlah 15 orang. (Sumber: Kantor Wali Nagari Koto Panjang). 
Berdasarkan data awal yang diperoleh dan wawancara awal peneliti dengan salah seorang orang tua yang memiliki anak usia sekolah, mereka ingin anak-anaknya bekerja di bidang pemerintahan, bidang kesehatan, dan bidang pendidikan, untuk mewujudkan cita-cita tersebut, mereka akan berusaha menyekolahkan anaknya sampai Perguruan Tinggi. Namun terkadang harapan tidak sesuai dengan kenyataan, salah satu kendalanya karena faktor ekonomi yang kurang mencukupi, anak ingin sekolah tinggi tapi ekonomi tidak memungkinkan, sebaliknya ekonomi orang tua mencukupi tapi anak tidak mau sekolah.

Fenomena tersebut menjelaskan bahwa aspirasi dan peran serta orangtua terhadap pendidikan anak sangat diperlukan, demi kemajuan dan keberhasilan pendidikan anak. Apabila peran serta orang tua baik dalam mendidik dan menunjang pedidikan anak, maka dapat menghasilkan sesuatu yang baik pula. Hal ini dapat dilihat dari cita-cita, hasrat, dan ketetapan hati orang tua.

Berdasarkan uraian di atas dapat disimpulkan bahwa aspirasi orang tua terhadap pendidikan anak adalah harapan atau keinginan orangtua untuk mencapai tingkat pendidikan anak yang diharapkan. Yang dimaksud aspirasi disini adalah untuk mengetahui apa yang menjadi harapan, keinginan dan tujuan orangtua demi pendidikan anaknya di masa yang akan datang. Anak sejak lahir membutuhkan pendidikan dari orang tua nya. Pendidikan dari orang tua sangat diperlukan anak dalam mengaktualisasikan potensi yang ada padadiri anak itu sendiri, setiap orangtua tentu saja mempunyai cita cita, tujuan dan harapan, itu akan tercapai bila anak dapat mencapai pendidikan dengan baik.

Hurlock (1980) mengemukakan mengenai aspek-aspek aspirasi yang berisi tiga hal, yaitu: (1) Cita-cita yaitu apa yang oleh individu dinilai penting dan ingin dicapai, selanjutnya disebut cita-cita. Cita-cita merupakan sesuatu yang ingin dicapai, diwujudkan dalam dunia nyata untuk waktu yang akan datang, yang merupakan idealisasi dari suatu bentuk kehidupan yang diinginkan, kehendak yang selalu ada di dalam pikiran. (2) Hasrat yaitu apa yang diharapkan individu dari apa yang dinilainya penting dan ingin dicapai tersebut, selanjutnya disebut hasrat atau keinginan. Hasrat merupakan sesuatu yang ingin diperoleh dari apa yang dilakukan baik untuk waktu dekat, maupun untuk jangka panjang. Hasrat lebih berkaitan dengan kemajuan diri dan peningkatan prestasi. (3) Ketetapan Hati yaitu seberapa nilai kepentingan bagi individu dari apa yang dinilainya penting dan ingin dicapai tersebut, selanjutnya disebut ketetapan hati. Ketetapan hati merupakan nilai dari sesuatu yang dinilai penting dan ingin dicapai, sebagai standar pencapaian dari apa yang dilakukan, tingkat kepuasan yang ingin dicapai dari apa yang dilakukan.

Menurut Hurlock (1999) bahwa faktor-faktor yang mempengaruhi aspirasi terdiri dari: (1) Faktor Internal, Adapun yang menjadi faktor internal yang mempengaruhi aspirasi yaitu: 
inteligensi, minat pribadi, pengalaman masa lampau, pola kepribadian, nilai pribadi, kompetisi, dan latar belakang ras. (2) Faktor Eksternal yang mempengaruhi aspirasi yaitu: ambisi orang tua, harapan sosial, dorongan keluarga, urutan kelahiran, dan tradisi budaya.

\section{METODE PENELITIAN}

Penelitian ini menggunakan jenis penelitian deskriptif kualitatif. Moleong (2010), mendefenisikan metodologi kualitatif sebagai prosedur penelitian yang menghasilkan data deskriptif berupa kata-kata tertulis atau lisan dari orang-orang dan perilaku yang diamati. Sedangkan menurut
Sugiyono (2003), penelitian kualitatif yang dipandang mampu melepaskan apa yang telah difikirkan sebelumnya, dan selanjutnya mampu melihat fenomenafenomena secara lebih luas dan mendalam sesuai dengan apa yang terjadi dan berkembang pada situasi sosial yang diteliti.

Lokasi penelitian ini dilakukan di Jorong Kampuang Pisang Kecamatan IV Koto Kabupaten Agam, lokasi ini sengaja dipilih karena peneliti ingin mengetahui bagaimana aspirasi orang tua tentang pendidikan anak di daerah tersebut. Waktu penelitian akan dilakukan pada bulan Februari - Maret 2018.

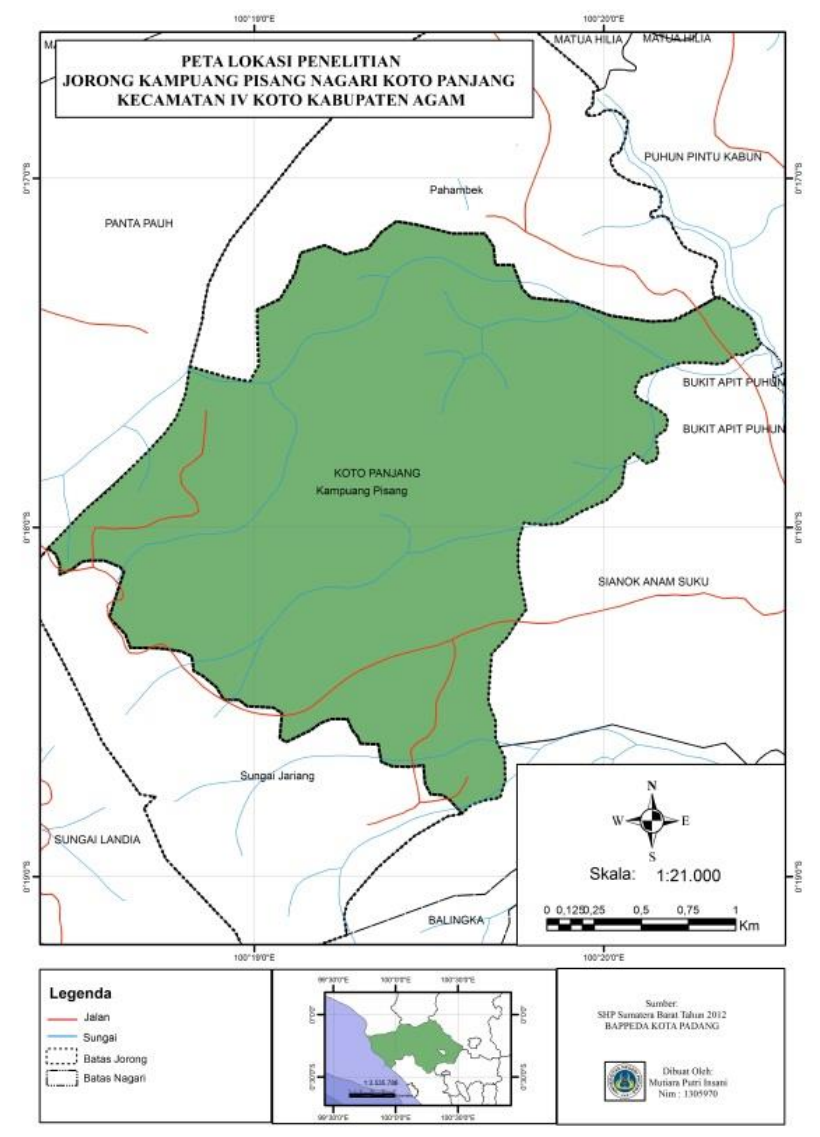

Gambar 1. Peta Lokasi Penelitian 
Subjek penelitian adalah pihakpihak yang dijadikan sebagai sampel dalam sebuah penelitian. Subjek penelitian dipilih dengan menggunakan teknik purposive sampling. Artinya menentukan pengambilan sampel dengan cara menetapkan ciri-ciri khusus yang sesuai dengan tujuan penelitian sehingga diharapkan dapat menjawab permasalahan penelitian.

Adapun yang menjadi subjek dalam penelitian ini adalah orang tua yang memiliki anak usia sekolah baik itu TK, SD, SMP, SMA, hingga Perguruan Tinggi. Adapun jenis data yang digunakan dalam penelitian ini adalah data kualitatif, yaitu data yang disajikan dalam bentuk verbal bukan dalam bentuk angka.

\section{HASIL DAN PEMBAHASAN}

Dari wawancara yang peneliti lakukan di Jorong Kampuang Pisang Nagari Koto Panjang pada bulan Januari - Februari 2018 diketahui secara umum aspirasi orang tua tentang pendidikan dapat dilihat dari cita-cita, hasrat, dan ketetapan hati.

Dari berbagai hasil wawancara, dapat disimpulkan bahwa orang tua memiliki cita-cita yang tinggi untuk anaknya seperti: menginginkan anaknya bekerja di bidang kesehatan, pemerintahan, pengusaha, guru, wanita karir dan lain sebagainya.

Hasrat merupakan sesuatu yang ingin diperoleh dari apa yang dilakukan baik untuk waktu dekat, maupun untuk jangka panjang. Disini hasrat bisa dikatakan usaha yang dilakukan untuk mencapai cita-cita orang tua terhadap anak.
Dari berbagai hasil wawancara dapat disimpulkan bahwa semua orangtua memiliki cita-cita yang tinggi untuk pendidikan anaknya, namun untuk mewujudkannya, orang tua akan melakukan usaha seperti: memilih pendidikan formal untuk anaknya. Tidak membedakan pendidikan untuk anak laki-laki dan pendidikan untuk anak perempuan, kebutuhan sekolah anak selalu diusahakan untuk memenuhi, walau sering terhambat karena faktor ekonomi. Orang tua selalu memotivasi anak agar selalu rajin belajar, walau dengan cara yang berbeda-beda bahkan ada yang hanya mengingatkan atau menasehati tapi tidak didampingi. Orang tua akan memberi hadiah jika anak mendapatkan prestasi disekolah.

Ketetapan hati merupakan nilai dari sesuatu yang dinilai penting, dan ingin dicapai, sebagai standar dari apa yang ingin dilakukan, tingkat kepuasan yang ingin dicapai dari apa yang dilakukan.

Pendidikan sangat penting untuk anak, karena dengan pendidikan anak akan mendapatkan bekal agar dia dapat bertahan hidup, dan melalui pendidikan anak dapat menyesuaikan diri dengan lingkungannya dan bekal untuk menghadapi persaingan di dunia luar (di luar keluarga). Pendidikan merupakan kebutuhan masyarakat sekarang, dengan pendidikan akan membentuk sumber daya manusia yang berkualitas.

Berdasarkan hasil penelitian yang telah ditemui peneliti saat di lapangan melalui observasi, wawancara, dan dokumentasi maka diperoleh hasil penelitian sebagai berikut: 
Pertama, Setiap orang tua pasti memiliki cita-cita agar anaknya bisa sekolah setinggi-tingginya dan nantinya bisa bekerja di tempat yang diinginkan. Peran orang tua mendidik anak dalam rumah tangga sangatlah penting, karena dalam rumah tanggalah seorang anak mula-mula memperoleh bimbingan dan pendidikan dari orangtuanya.

Seorang ibu memegang peranan penting dalam mendidik anak di lingkungan rumah tangga, sebab ibulah yang hampir setiap hari berada dirumah. Seorang Ibu harus menjadi tokoh utama dalam pekerjaan mendidik anakanaknya (Henry N. Siahaan, 1991).

Peran ayah dalam keluarga tidak hanya bertanggung jawab mencari nafkah, ayah juga perlu turut bertanggung jawab dalam perawatan, penjagaan, pendidikan, dan membimbing anak-anaknya bersamasama dengan sang istri (Henry N. Siahaan, 1991).

Oleh sebab itu kerjasama antara ibu dan ayah dalam sebuah keluarga sebagai orangtua sangatlah penting untuk mendidik anaknya secara bersama agar tercapainya kesuksesan dalam pendidikan anak.

Aspirasi orang tua terhadap pendidikan anak sangat diperlukan untuk menunjang pendidikan yang lebih baik. Dalam hal ini orang tua sebagai agen utama untuk pendidikan anak, orang tua ikut berperan serta dalam pemilihan pendidikan untuk anakanaknya. Harapan orang tua yang positif terhadap pendidikan anak juga akan berpengaruh langsung terhadap pendidikan anak-anaknya.
Kedua, Dalam hal ini, usaha orang tua dalam mewujudkan cita-cita terhadap anaknya sangat penting.Orang tua memasukkan anaknya ke sekolah formal ditambah dengan sekolah nonformal seperti kursus. Orang tua juga tidak membeda-bedakan pendidikan untuk anak laki-laki dan anak perempuan, karena mereka memiliki hak yang sama dalam memperoleh pendidikan. Cara orang tua memotivasi anaknya agar rajin belajarpun berbeda-beda, ada yang hanya mengingatkan, ada juga yang ikut mendampingi anak dalam belajar. Bahkan, jika anak berprestasi, maka akan diberikan hadiah baik itu berupa barang, uang, maupun pergi liburan. Faktor ekonomi juga sering menjadi kendalanya, ada orang tua yang ingin menyekolahkan anaknya setinggi mungkin, tapi terkendala faktor ekonomi yang tidak mencukupi. Begitupun sebaliknya, ada orang tua yang mampu menyekolahkan anaknya, tapi anak tersebut yang tidak mau sekolah.

Undang-Undang Nomor 20 tahun 2003 tentang Sistem Pendidikan Nasional merupakan undang-undang yang mengatur sistem pendidikan yang ada di Indonesia. Dalam UU ini, penyelenggaraan wajib memegang beberapa prinsip antara lain pendidikan diselenggarakan secara demokratis dan berkeadilan serta tidak diskriminatif dengan menjunjung tinggi nilai hak asasi manusia, nilai keagamaan, nilai budaya dan kemajemukan bangsa dengan satu kesatuan yang sistematis dengan sistem terbuka dan multimakna. 
Selain itu, di dalam penyelenggaraannya sistem pendidikan juga harus dalam suatu proses pembudayaan dan pemberdayaan peserta didik yang berlangsung sepanjang hayat dengan memberi keteladanan, membangun kemauan (niat, hasrat), dan mengembangkan kreativitas peserta didik dalam proses pembelajaran melalui mengembangkan budaya membaca, menulis, dan berhitung bagi segenap warga masyarakat melalui peran serta dalam penyelenggaraan dan pengendalian mutu layanan pendidikan.

Ketiga, Cita-cita orang tua yang beragam terhadap anak ada yang terwujud, ada juga yang tidak. Hal tersebut bisa akan menghasilkan tingkat kepuasan dari apa yang telah dilakukan. Orang tua memasukkan anaknya kesekolah formal kemudian dilanjutkan ke Perguruan Tinggi yang sesuai dengan minat anak dan keinginan orang tua, dengan harapan agar cita-cita orang tua terhadap anak bisa terwujud. Jika harapan tersebut terwujud, maka orang tua pasti merasa senang dan puas karena jerih payah mereka selama ini terbayarkan dengan berhasilnya anak dalam pendidikan dan pekerjaan. Begitupun sebaliknya, orang tua akan merasa sedih, dan tidak puas jika apa yang diharapkannya tidak sesuai dengan kenyataan, tapi tetap bisa menerima kenyataan.

Orang tua berpandangan bahwa pendidikan anak itu sangat penting, orangtua berpendapat bahwa dengan memperoleh pendidikan wawasan anak akan lebih luas dan dapat menjadi bekal anak dimasa yang akan datang.
Orangtua memilihkan jenis pendidikan untuk anak-anaknya, seperti memilihkan pendidikan atau sekolah negeri untuk anak-anaknya, orang tua memberikan pengertian kepada anak, seperti mengatur waktu belajar anak dirumah, memenuhi segala kebutuhan sekolah anak, memberikan motivasi atau dorongan kepada anak untuk belajar, mengajak berkomunikasi atau bertukar fikiran dengan anak, memberikan hadiah atau penghargaan kepada anak apabila mendapatkan prestasi di sekolah.

Aspirasi orang tua terhadap pendidikan anaknya adalah agar anaknya memperolah bekal dan ilmu pengetahuan yang berguna serta mengharapkan agar sekolah atau institusi pendidikan yang didapat oleh anaknya merupakan sekolah yang berkualitas baik sehingga anak pun memperoleh pengetahuan yang bermutu. Orang tua berusaha mendorong anak-anaknya untuk dapat melanjutkan sekolah setinggi-tingginya yang mengandung harapan setelah anak selesai menempuh pendidikan dapat pekerjaan yang baik atau layak dan bisa lebih baik dari orangtuanya. Dalam penelitian ini, orangtua memiliki aspirasi yang positif untuk menunjang pendidikan anaknya.

Berdasarkan pembahasan diatas, orang tua yang memiliki anak usia sekolah memiliki aspirasi yang positif untuk pendidikan anaknya, namun cara orang tua dalam memberikan motivasi agar anak rajin belajar berbeda-beda.

Selanjutnya peneliti akan menyimpulkan aspirasi orang tua tentang pendidikan anak di Jorong 
Kampuang Pisang yang memiliki tiga Dusun. Pertama Kampuang Pisang Atas, orang tua di Dusun ini memiliki aspirasi yang positif tentang pendidikan anak namun, orang tua hanya memberikan nasihat agar anak rajin belajar tanpa mendampingi anak tersebut dalam belajar. Kedua Kampuang Pisang Bawah juga memiliki aspirasi yang positif tentang pendidikan anak, namun disini orang tua lebih perhatian kepada anaknya dalam arti ikut serta mendampingi anak belajar. Ketiga Bukik gadang juga memiliki aspirasi yang positif tentang pendidikan anak, namun orang tua juga memberikan nasihat agar anak rajin belajar, dan dijanjikan hadiah jika anak berprestasi.

\section{PENUTUP}

\section{Kesimpulan}

Setelah melakukan rangkaian penelitian penulis dapat menyimpulkan hal-hal sebagai berikut:

1. Aspirasi orang tua terhadap pendidikan anak adalah orangtua mempunyai keinginan atau harapan yang positif terhadap pendidikan anaknya yaitu dengan memilih pendidikan formal. Cita-cita orang tua terhadap pendidikan anaknya yaitu orang tua ingin anaknya bekerja di Bidang Pemerintahan, Bidang Kesehatan, Bidang Pendidikan, dan lain sebagainya.

2. Hasrat berkaitan dengan usaha orang tua untuk mewujudkan cita-cita orang tua terhadap anaknya, seperti memasukkan anak ke sekolah formal, tidak membedakan pendidikan antara anak laki-laki dan anak perempuan, dan berusaha memenuhi kebutuhan anak walau sering terkendala biaya.

3. Ketetapan hati berkaitan dengan kepuasan orang tua terhadap apa yang telah dicapai anaknya, orang tua merasa puas jika cita-cita mereka terhadap anak bisa terwujud.

\section{Saran}

Berdasarkan kesimpulan diatas, maka beberapa saran yang dapat peneliti berikan adalah sebagai berikut:

1. Agar orang tua lebih memperhatikan lagi pendidikan anaknya, jangan biarkan anak belajar sendiri tanpa di dampingi karena anak butuh tempat bertanya jika ada hal yang membuat anak ragu.

2. Usahakan anak mendapatkan pendidikan setinggi-tingginya, semoga apa yang dicita-citakan bisa terwujud.

\section{DAFTAR PUSTAKA}

Ahmadi, A. 2009. Psikologi Umum. Jakarta : Rineka Cipta.

Henry, N. Siahaan. 1991. Peran Ibu Bapak Mendidik Anak. Bandung: Angkasa Bandung

Hurlock, E.B. 1980. Psikologi Perkembangan Suatu Pendekatan Sepanjang Rentang Kehidupan. Alih Bahasa: isti Widayanti \& Soedjarwo. Jakarta: Erlangga (Edisi ke-5).

Hurlock, E.B. 1999. Perkembangan Anak . Jilid 2. Alih Bahasa: Meitasari Tjandrasa. Jakarta: Erlangga (Edisi ke-6) 
Kamus Besar Bahasa Indonesia (KBBI).

Jakarta : Balai Pustaka

Moleong, Lexy J. 2010. Metode

Penelitian Kualitatif. Bandung: PT

Remaja Resdakarya

Slameto. 2010. Belajar dan Faktor-

Faktor yang Mempengaruhinya.

Jakarta: Rineka Cipta

Sugiyono. 2003. Metodelogi Penelitian

Kualitatif. Bandung: Alfabeta.

Undang Undang Nomor 20 tahun 2003

tentang Sistem Pendidikan

Indonesia 